\title{
A TRAJETÓRIA INTELECTUAL E OS PRIMEIROS ESCRITOS MARXISTAS DE LUCIEN GOLDMANN (1927- 1952)
}

\author{
INTELLECTUAL TRAJECTORY AND EARLY MARXIST WRITINGS \\ BY LUCIEN GOLDMANN (1927-1952)
}

João Alberto da Costa Pinto ${ }^{1}$

RESUMO: Neste artigo descrevo a trajetória biográfico-intelectual de Lucien Goldmann, um destacado autor nos quadros do que se convencionou chamar de "marxismo ocidental". O artigo apresenta uma descrição dos seus experimentos políticos de juventude junto à esquerda judaica romena na década de 1920; destaca o período em Paris e Toulouse como refugiado político do fascismo romeno; descreve a sua prisão durante o Governo Vichy; e termina desenvolvendo uma análise pormenorizada dos estudos sobre Kant realizados na Suíça e a consequente formulação de um projeto teórico marxista independente no meio acadêmico francês da década de 1950, quando publicou o livro Ciências Humanas e Filosofia (1952).

PALAVRAS-CHAVE: Lucien Goldmann; marxismo kantiano; visões de mundo; consciência possível; fascismos na Romênia e França.

ABSTRACT: This article addresses the biographical and intellectual trajectory of Lucien Goldmann, a major figure in what has become known as Western Marxism. It presents his political experimentations with the Romanian Jewish left during his youth in the 1920s, the period spent in Paris and Toulouse as a political refugee fleeing Romanian Fascism, as well as his imprisonment during the Vichy government. Lastly, the article offers an in-depth analysis of his studies on Kant in Switzerland and his subsequent formulation of an autonomous, Marxist-oriented theoretical project within French academia in the 1950s, which led to the publication of The Human Sciences and Philosophy in 1952.

\footnotetext{
* Este artigo resulta de pesquisa em andamento que desenvolvo junto ao PPGH/UFG sobre um conjunto de trajetórias de intelectuais marxistas autonomistas, dissidentes da tradição marxistaleninista europeia (no período de 1950-1970), que além de Lucien Goldmann, envolve também as trajetórias de Serge Mallet, Guy Debord e Raoul Vaneigem (França), Raniero Panzieri e Mario Tronti (Itália) e João Bernardo (Portugal).

${ }^{1}$ Professor Doutor no Programa de Pós-Graduação em História da Universidade Federal de Goiás (PPGH/UFG). Telefone: (62) 3521-1130. Email: joaoacpinto@ yahoo.com.br
} 
KEYWORDS: Lucien Goldmann; kantian marxism; worldviews; potential consciousness; fascisms in Romania and France.

Neste artigo apresento um estudo sobre o percurso teórico-político de Lucien Goldmann definindo o personagem como um importante capítulo na história do marxismo ocidental ${ }^{2}$ no século XX. Enfatizo os seus experimentos políticos de juventude junto à esquerda judaica romena na década de 1920 e os primeiros momentos da sua trajetória acadêmica como um outsider, um marxista dissidente do cânone marxista-leninista que atuava com bastante independência no interior da universidade francesa no início da década de 1950, principalmente quando da publicação do livro Ciências Humanas e Filosofia no ano de 1952.

A obra de Lucien Goldmann teve ampla repercussão nos debates marxistas das décadas de 1960 e 1970. Parte significativa da sua produção foi traduzida no Brasil nesse período, mas, ainda assim, é um autor pouco conhecido e pouco referenciado no âmbito da historiografia brasileira. No Brasil, os trabalhos de Michael Löwy e Celso Frederico são praticamente os únicos que apresentam sistematicamente a obra e a trajetória de Goldmann ${ }^{3}$. O

\footnotetext{
${ }^{2} \mathrm{O}$ termo marxismo ocidental é uma denominação tradicional na historiografia contemporânea, usada para delimitar um movimento de ideias e autores marxistas oposto às tradições da ortodoxia marxista soviética sustentadas em grande parte na matriz do positivismo naturalista engelsiano (de livros como o Anti-Duhring, por exemplo). Um dos textos clássicos para a caracterização historiográfica do marxismo ocidental é o livro As aventuras da dialética, que Maurice Merleau-Ponty (2006) publicou em 1955 (ver, especialmente, os capítulos 2 e 3). O marxismo ocidental é definido como um retorno do marxismo à matriz historicista hegeliana, assinalada na obra de Marx. O livro História e consciência de classe, de Georg Lukács, publicado em 1923, é unanimemente reconhecido como o documento maior do marxismo ocidental. Em suma, contra o positivismo marxista-leninista de matriz engelsiana (na noção de "dialética da natureza"), o marxismo ocidental remete sua estrutura teórica a conceitos centrais na obra de Marx, como os conceitos de totalidade e o de reificação. Sobre a história do marxismo ocidental, consultar também os livros de Anderson (1989), de Arato e Breines (1986) e o de Jay (2008).

${ }^{3}$ Michael Löwy é autor junto com Sami Nair do livro Lucien Goldmann: ou a dialética da totalidade (2008), além de inúmeros artigos e capítulos de livros dedicados ao pensamento de Lucien Goldmann, que foi o seu orientador de tese de doutorado em Filosofia na Sorbonne. Celso Frederico, além de ter publicado vários artigos sobre a trajetória de Goldmann, é autor do importante livro Sociologia da cultura: Lucien Goldmann e os debates do século XX (2006). As notícias biográficas que Löwy apresenta sobre a trajetória de Goldmann baseiam-se num pequeno texto, intitulado "L'Auteur" (1971a), de Annie Goldmann (esposa de Goldmann), publicado como anexo no livro de Goldmann (1971b). Já Celso Frederico baseia suas
} 
propósito central deste artigo, para além da formulação de uma síntese conceitual sobre as primeiras obras de Goldmann, é o de apresentar a perspectiva teórica do marxismo goldmanniano como uma significativa ferramenta de investigação para os estudos historiográficos, especialmente aqueles desenvolvidos nos campos da História Intelectual e da História Social das Ideias ou ainda no campo da História da Historiografia.

Juventude e militância política em Botosani e Bucareste (1927-1934)

A trajetória de Lucien Goldmann foi bastante acidentada nos seus anos de formação intelectual. Antes de se destacar como um importante quadro do cenário acadêmico europeu na década de 1960, ocupando o cargo de diretor de Estudos na École Pratique des Hautes Études (6 ${ }^{\mathbf{a}}$. Seção), em Paris, foi estudante, militante, pesquisador e professor na Romênia, Áustria, Suíça e na Bélgica. Trata-se de um percurso de formação marcado por enormes dificuldades, diante da conjuntura dos fascismos europeus, pelo fato de Goldmann ser judeu ${ }^{4}$. Um judeu pobre e que desde a sua adolescência em Bucareste militou junto a grupos marxistas. De acordo com Mitchell Cohen (1994), autor da mais completa investigação já feita sobre a trajetória de Lucien Goldmann, a experiência militante junto a grupos marxistas como o Ha-Shomer ha-Tsair ${ }^{5}$, importante grupo sionista/comunista na cidade de Botosani

informações biográficas principalmente com o excelente livro de Mitchell Cohen (1994), livro, aliás, que utilizo sistematicamente na primeira parte deste artigo.

4 Goldmann nasceu em Bucareste, Romênia, em 20 de junho de 1913, filho de Joseph Goldmann e Serafina Goldmann. Escreve Cohen (1994) que Joseph Goldmann era um judeu secular com atividades prósperas no comércio e que veio a falecer aos 36 anos por causa de uma sífilis crônica, quando "Gica" (o apelido de Goldmann) estava com sete anos de idade. A morte do pai deixa Serafina Goldmann em grandes dificuldades econômicas. Considerada uma mulher muito culta, foi uma grande influência na formação cultural de Goldmann, que foi alfabetizado por ela em várias línguas. Segundo Cohen (1994), Goldmann teve pouco contato com a mãe depois que saiu de Bucareste em 1930. Reencontraram-se em Paris quando ela veio a falecer meses antes da morte prematura de "Gica", ocorrida em 8 de outubro de 1970.

${ }^{5} \mathrm{O}$ grupo Ha-Shomer ha-Tsair (ou Hashomer Atzair) (Jovem Guarda) foi fundado em 1913 na Galícia austríaca e depois organizado em vários países da Europa Central e ainda é um grupo atuante da comunidade judaica internacional, presente, inclusive em várias cidades brasileiras. Foi organizado como órgão da juventude sionista e era um grupo bastante atuante da juventude socialista (socialismo agrarista que tinha como um dos seus objetivos a colonização agrária da Palestina) de Botosani, cidade ao norte da Romênia, na região da Moldávia (não confundir com 
(Romênia), foi decisiva para a definição das perspectivas ideológicas do autor. Diz Cohen (1994) que a presença do marxismo revisionista de Max Adler nos debates internos do Hashomer Atzair definiu o interesse de Goldmann pela obra de Immanuel Kant, reiterado posteriormente, em 1930, quando, por um breve período, foi aluno de Adler na Universidade de Viena. O primeiro livro de Goldmann (publicado em alemão em 1945 e em francês em 1948), originado da sua tese de doutorado em Filosofia (defendida em Zurique em 1945), sistematiza um estudo sobre as origens da dialética em Kant, no qual, como apresento adiante, sustenta o argumento de ser a obra do filósofo prussiano um termo de seminal importância à estruturação do pensamento de Karl Marx.

Em 1927, com 14 anos, Goldmann vinculou-se como militante do Hashomer Atzair em Botosani. Cohen (1994: 22) afirma que esse ingresso no grupo socialista sionista foi estimulado pela mãe, dadas as condições de ser um “jovem solitário" portador de uma pequena deformidade física (Goldmann era corcunda) que procurava esconder com exercícios físicos (praticava remo). Com uma militância ativa, em três anos tornou-se um dos líderes do grupo. De origens romântico-agraristas, o movimento Hashomer Atzair aproximou-se do marxismo em fins da década de 1920, circunstância que leva Goldmann a estudar o marxismo pela primeira vez. Em face da conjuntura política do crescente antissemitismo na política romena, o grupo aprofundou os estudos no marxismo e aproximou-se do Partido Comunista Romeno (PCR). O destaque intelectual de Goldmann levou-o a outras esferas de atuação pública na cidade. Além da aproximação com o Partido Comunista que o leva a abandonar o Hashomer Atzair em 1930, passou a frequentar com bastante entusiasmo o Círculo de Leitura de Botosani (fundado em 1908), que reunia intelectuais liberais e socialistas (incluídos intelectuais do PCR) da cidade. Com 17 anos, Goldmann ministrava ali palestras sobre literatura. Afirma Cohen (1994) que a participação nesse Círculo, ainda que restrita ao ano de 1930 (a instituição foi fechada em 1938 a mando do Rei Carol II, pelo fato de ser um cenáculo de

a República da Moldávia, país que faz fronteira com a Romênia), onde Goldmann passou parte da sua infância e juventude. 
intelectuais de esquerda), foi de suma importância para a formação intelectual de Goldmann.

Também em 1930, durante alguns meses, frequentou algumas das aulas de um curso de Economia Política ministradas por Max Adler na Universidade de Viena. Adler era a grande referência do austro-marxismo ${ }^{6}$. Goldmann já estava familiarizado com a obra de Adler, pois no Hashomer Atzair havia uma "tendência Max Adler" (COHEN, 1994: 25). O marxismo de Max Adler e de outros austro-marxistas neokantianos, como Karl Renner e Rudolf Hilferding, foi decisivo na formação intelectual de Lucien Goldmann e uma das consequências dessa conexão, como afirma Cohen (1994), foi o interesse de Goldmann em estudar sistematicamente de um ponto de vista marxista a obra filosófica de Immanuel Kant.

Em 1931 inicia os seus estudos na Faculdade de Direito da Universidade de Bucareste, diplomando-se em dezembro de 1934. A presença e os preconceitos generalizados do antissemitismo que ali encontrou marcaram o percurso de Goldmann naquela universidade. Residia no famoso Dormitório Schuller, um prédio residencial situado no bairro judeu de Bucareste e famoso por abrigar estudantes judeus pobres. Esse local que frequentemente era alvo de ataques antissemitas ${ }^{7}$ estava sob a administração da União Geral dos Estudantes

\footnotetext{
${ }^{6}$ Max Adler foi um importante teórico do austro-marxismo, corrente de ideias que era marcada pela forte presença da obra de Kant no revisionismo marxista. Os intelectuais austro-marxistas são expressão ideológica clássica tanto do revisionismo socialdemocrata quanto do conselhismo na Europa das décadas de 1920 e 1930. Adler foi um crítico de primeira hora do bolchevismo de Lênin na Revolução Russa. Defensor dos Conselhos Operários propunha a radicalização da democracia social em detrimento da democracia política do Partido-Estado. Segundo Leszek Kolakowsky (1983), no seu modelo teórico, Max Adler aproximou a teoria crítica kantiana ao marxismo. Para ele o conceito marxiano de "ser social" encontrava uma melhor fundamentação na categoria de consciência transcendental de Kant, o que lhe demonstrava que a socialização dos indivíduos não era simplesmente um fato histórico, mas parte integrante de constituição da consciência, um atributo de todos os indivíduos como seres humanos (KOLAKOWSKY, 1983). Alguns ensaios políticos de Adler sobre a história da democracia social em contraste com a democracia burguesa, especialmente estudos sobre práticas de organização dos conselhos dos trabalhadores russos diante dos impasses da Revolução Russa de 1917, podem ser lidos em Adler (1976). Sobre Max Adler e o austro-marxismo, consultar também Andrew Arato (1986).

${ }^{7} \mathrm{Na}$ Romênia da década de 1930, sob o governo do Rei Carol II, eram habituais os violentos ataques das milícias da Guarda de Ferro, associadas à Legião do Arcanjo São Miguel, "o mais arrebatadamente religioso de todos os partidos fascistas" da Europa (PAXTON, 2007: 166), liderado por Corneliu Codreanu de 1927 a 1938, contra os comunistas e judeus. Com a queda do Rei Carol II em 1939, o país, sob o comando do General Antonescu, um fascista radical que governaria o país até 1945 , além de manter a perseguição à comunidade judaica e aos
} 
Judeus, entidade controlada pela União da Juventude Comunista, órgão clandestino ligado ao Partido Comunista Romeno. Goldmann, além de morador, teve ali uma importante atuação como militante por meio das inúmeras palestras ministradas (COHEN, 1994). Essas palestras, que iam de temas como a física de Einstein, a psicanálise de Freud e o marxismo de Max Adler, deram-lhe fama entre os colegas da casa. Com ele viviam ali alguns estudantes que mais tarde viriam a se tornar políticos de expressão nacional. Além de residência e espaço de reuniões políticas, no Dormitório Schuller também se organizou um jornal de impacto junto ao movimento estudantil da universidade: a Tribuna dos Estudantes Pobres (Tribuna Studentului Sarac), periódico de circulação clandestina para o qual Goldmann colaborou com vários artigos (COHEN, 1994). No seu livro, Michell Cohen relata as dificuldades para a reconstrução historiográfica da trajetória de Goldmann nesse período, mas ressalva dois fatos, duas situações, de suma importância. A primeira refere-se ao Partido Comunista Romeno, que, no começo da década de 1930, transformou-se num satélite da Internacional Comunista de Moscou, aspecto que se verificou com a ortodoxia stalinista nas diretrizes programáticopolíticas do partido, termo esse que atingiu frontalmente a independência teórica e política de Lucien Goldmann. Nessa altura, além de ser visto, em meio aos seus colegas de universidade, com livros de Trotsky, Goldmann também chamava Stálin de "assassino" (COHEN, 1994: 36), o que naquela conjuntura era uma heresia política de graves repercussões que o levou ao isolamento entre os estudantes comunistas. Cohen (1994: 36) diz que Goldmann era um "dissidente" entre os estudantes e militantes do partido comunista. O outro fato destacado foi a sua prisão em 1933 (três meses), por ter participado dos atos de apoio dos estudantes à greve dos trabalhadores ferroviários de Bucareste ocorrida naquele ano, incidente em que mais de dois mil estudantes e trabalhadores foram presos (COHEN, 1994).

estudantes "judeus-bolcheviques" fez do país um dos principais fornecedores de petróleo da Alemanha de Hitler. Sobre a experiência fascista na Romênia consultar Bernardo (2003: 116120 e 813-814), Paxton (2007: 44 e 166-167), Mann (2008: 351-394) e Mazower (2001: 137). 
Dois fatores levaram Goldmann a sair de Bucareste: a presença dramática do antissemitismo fascista dos legionários de Codreanu, que na cidade perseguiam sistematicamente os estudantes judeus do Dormitório Schuller, e a marca do intelectual dissidente que agregou a si diante do stalinismo hegemônico. Ressalve-se que o fascismo das legiões de Codreanu teve nas suas fileiras intelectuais de expressão internacional - Mihail Manoilesco, Emil Cioran e Mircea Eliade foram alguns desses intelectuais. Todos apoiaram a alternativa fascista-corporativista dos governos do Rei Carol II e do general Antonescu nas décadas de 1930 e 1940. Mas foi nas práticas dos legionários do Arcanjo São Miguel, extremamente violentas, que a comunidade judaica (e militantes comunistas) de Bucareste se viu cotidianamente afrontada, práticas que se mantiveram após o assassinato de Codreanu em 1938, quando em 21 de janeiro 1941 os legionários sob a liderança de Horia Sima, um professor de literatura que dividia o governo com o general Antonescu, mataram mais de dois mil judeus na cidade. Era na capital Bucareste que se concentravam historicamente as comunidades judaicas romenas, o equivalente a 12\% da população da cidade (MANN, 2008: 381), e foi ali, portanto, que a repressão ao pequeno Partido Comunista e aos estudantes judeus e comunistas ("judeus-bolcheviques" como eram chamados) foi bastante acentuada (BERNARDO, 2003; MANN, 2008; PAXTON, 2007). Logo após a conclusão do curso de Direito, em dezembro de 1934, Goldmann saiu definitivamente de Bucareste e exilou-se em Paris, França. Paris foi o destino de muitos outros intelectuais judeus dissidentes, romenos e do leste europeu, caso, por exemplo do escritor dramaturgo romeno Eugène Ionesco ${ }^{8}$. Lucien Goldmann nunca mais voltou à Romênia. Aos 21 anos carregava consigo o prestígio intelectual marcado pela dissidência política entre os comunistas, o que lhe afirmava individualmente uma marca que o acompanharia por toda a vida: a independência intelectual. E dos seus estudos em Bucareste (e Viena) carregou a repercussão estruturante do marxismo neokantiano de Max Adler e a

\footnotetext{
${ }^{8}$ Michael Mann (2008) afirma que a composição da famosa peça de teatro $O$ rinoceronte (1960), de Ionesco, foi inspirada pelos fatos e práticas cotidianas do fascismo romeno presenciados pelo autor em Bucareste na década de 1930.
} 
necessidade de estudar a filosofia de Kant para melhor compreender Marx e as tradições dos marxismos que lhe eram contemporâneas.

Estudos, exílio, miséria e prisão na fuga do fascismo (Paris, Toulouse e Zurique: 1935-1945)

Lucien Goldmann estabeleceu-se em Paris no começo de 1935. Nos anos seguintes, até 1938, frequentou dois cursos, um bacharelado em Economia na Universidade de Paris e uma Licenciatura em Literatura na Universidade da Sorbonne. Como todos os intelectuais judeus exilados naquela cidade, sofreu as duríssimas condições de miséria, acentuadas em 1940 quando a cidade foi ocupada pelas tropas nazistas. Em 1935 a França mantinha-se como a esperança antifascista da Europa, acentuada ao final do ano, quando se desenharam as condições para organização e eleição de um judeu para o governo da República. Trata-se de Leon Blum, esse "Judeu de Estado", em termo que Toni Judt (2014, p. 64) usa para descrever "judeus secularizados dedicados ao serviço público" da República. Liderando a Frente Popular, Blum governaria o país de 1936 a 1937, retornando ao governo em $1938^{9}$. Para os que fugiam do fascismo, como

\footnotetext{
${ }^{9}$ O governo da Frente Popular foi uma coalização de partidos de esquerda coordenada pela Seção Francesa da Internacional Operária (SFIO), um partido socialista liderado por Léon Blum. O governo de coalizão foi formado em junho de 1936, reunindo, além da SFIO, o Partido Comunista Francês (PCF) e os radicais independentes (do Partido Radical). A coalização socialista democrática propunha-se a enfrentar as inúmeras ligas fascistas que apareciam na França, mas, principalmente, a combater a Ação Francesa (Action Française). Em fevereiro de 1934 Paris foi tomada por agitações fascistas. Léon Blum com a SFIO propôs àquela altura a coalizão antifascista que só vingaria dois anos depois, com o PCF e com o Partido Radical. A maior liderança comunista do PCF, Jacques Doriot, era amplamente favorável à aliança proposta pela SFIO de Blum e, em ato dissidente com o partido, movimentou seu colégio eleitoral parisiense (no bairro operário de Saint Denis) a favor da coalização. Doriot, um histórico sindicalista comunista, foi expulso do PCF (em junho de 1934) pelo ato dissidente contrário ao programa do Komintern, que naquele momento ainda insistia em ver os socialistas da SFIO como inimigos de classe dos comunistas, sem dar a devida atenção às ligas fascistas que brotavam por todos os lados. Fora do PCF, Doriot fundou em fins de 1936 o Partido Popular Francês, que em 1938 chegou a ter mais de 300 mil filiados, muitos desses, oriundos do PCF e da SFIO. Visto como de extrema-esquerda, Doriot, antes mesmo de formar o seu partido, passou a defender em 1935 uma aproximação da França com a Alemanha (a França nesse ano fizera um acordo internacional com a URSS), pois acreditava assim preservar a paz mundial. $\mathrm{O}$ fato é que, com uma ampla base social apoiando as inúmeras manifestações fascistas, o governo do primeiro-ministro Léon Blum pouco conseguiu fazer para obstar o fascismo. Três meses antes de assumir o governo, Blum foi brutalmente espancado na rua por milicianos da Ação Francesa, então o mais famoso grupo político do fascismo francês, liderado por Charles Maurras (cuja obra foi muito lida pelo salazarismo em Portugal e que teve no Brasil, em
} 
Goldmann, o governo da Frente Popular, ainda que bastante frágil e ambíguo na sua constituição política, foi durante breve período um oásis em meio aos fascismos no continente europeu. Com a queda de Leon Blum em 1938, a França capitularia logo a seguir o seu destino de uma democracia republicana quando se consorciou com a ocupação nazista na criação do governo colaboracionista do Marechal Petáin, naquilo que ficou conhecido como Governo de Vichy (1940-1944). A situação da esquerda francesa, especialmente com o PCF, foi dramaticamente agravada após a notícia do acordo de paz de 1939 assinado por Hitler e Stálin. Com o início da guerra provocado pelas invasões da Alemanha, incluída a ocupação da França em 1940, Moscou impunha como norma política aos comunistas franceses a obrigação de criticarem a aliança de França e Inglaterra como um ato imperialista contra a Alemanha, e vários dirigentes do PCF foram presos por discordarem de tais diretrizes (BERNARDO, 2003; LOTTMAN, 1987).

Lucien Goldmann viveu em Paris sob condições absolutamente precárias. Sobrevivia trabalhando como lavador de pratos em restaurantes e como entregador de jornais, como também escrevia e vendia monografias de final de curso para estudantes ricos dos cursos de Direito. Com a indicação de alguns amigos, como a do filósofo Vladimir Jankelevitch, por algum tempo (de

Gilberto Freyre, um dos seus grandes admiradores). Maurras dizia que Blum era "um homem a abater, mas pelas costas [...] detrito humano que deve ser tratado como tal" (apud JUDT, 2014: 112). O fascismo da Ação Francesa teve o apoio de inúmeros intelectuais que conviviam com o cotidiano de Goldmann. Philippe Ariès, que viria a ser um historiador de destaque, era um desses "maurrasistas", que dizia a seus amigos: "Sou capaz de identificar um judeu pelo cheiro" (apud RIDING, 2014: 31). Os labirintos da governabilidade socialista de Léon Blum no comando da Frente Popular em defesa da democracia arruinaram-se rapidamente não só pela complexa fragmentação do campo político de esquerda, mas também pelos violentos ataques das milícias fascistas (camelots du roi, ligados a Maurras, e os milicianos assassinos da La Cagoule, os cagoulards, um grupo terrorista organizado e financiado por Eugène Schueller, o fundador da L'Oreal, a ainda hoje famosa empresa de cosméticos). Um exemplo: naquele curto período de 1935 a 1938, o país viu Jacques Doriot transformar-se na mais expressiva liderança da esquerda comunista em 1935 e a afirmar-se, já em 1938, com o seu PPF, como um dos principais protagonistas do fascismo que depois se consorciariam com os nazistas no governo colaboracionista da República de Vichy. Foi morto em fevereiro de 1945, metralhado por um avião inglês, quando fugia de carro para a cidade de Sigmaringen, no sudoeste da Alemanha, ocasião em que se formava ali o "governo Vichy no exílio", que foi desfeito em abril de 1945, com a tomada da cidade pelas tropas aliadas. Para mais informações e detalhadas análises sobre esses personagens em tais conjunturas políticas, consultar os trabalhos indispensáveis de João Bernardo (2003: 136-151, 529-538), de Alan Riding (2014: 30-31, 164-166) e o de Tony Judt (2014: 47-124). 
novembro de 1939 a junho de 1940, por exemplo) também deu aulas de alemão num colégio nos arredores de Paris (COHEN, 1994). Goldmann era um arquétipo social do intelectual judeu exilado na cidade. Entre os estudos e os trabalhos manteve contato com outros intelectuais judeus exilados em trajetórias similares à sua. Manteve conversas com Walter Benjamin, o pensador marxista alemão que viria a se suicidar em 1940 em dramática tentativa de fuga para os Estados Unidos; encontrou-se e manteve longa amizade com o filósofo húngaro Joseph Gabel, também judeu, que se faria um dos nomes de grande expressão do marxismo na década de 1960, com seus estudos sobre a alienação, e um dos responsáveis pela apresentação da obra de Georg Lukács a Goldmann. A cultura marxista francesa muito deve à presença desses intelectuais exilados. Se Goldmann já poderia ser percebido como um jovem marxista "adleriano", outros intelectuais apresentavam-lhe agora a matriz lukacsiana e, além deles, também repercutiam na cidade as conferências que Alexandre Kojève, filósofo russo refugiado em Paris, ministrava sobre a obra de Hegel na École Pratique des Hautes Études. Seu curso de introdução à Fenomenologia do Espírito de Hegel realizado de 1933 a 1939 teve a audiência de ilustres alunos como Jean-Paul Sartre e Jacques Lacan. Alexandre Kojève seria de fundamental importância para a presença da obra de Hegel na cultura francesa, termo que teve consequências diretas para a formação da cultura marxista nas décadas de 1940 e 1950, por causa de temas como a alienação/reificação centrais nas perspectivas hegelianas do marxismo humanista francês nos debates com os marxismos estruturalistas nas décadas de 1950 e 1960 (COHEN, 1994).

Ainda que existissem algumas organizações de apoio, pouca ajuda havia aos intelectuais refugiados em França. Herbert Lottman (1987) descreve em detalhes as grandes dificuldades desses intelectuais exilados na cidade de Paris. Sem trabalhos regulares, sobreviviam precariamente. Uma marca que aparece em todas as memórias dos intelectuais citados por Lottman eram a fome e o terrível frio dos invernos vividos sem calefação alguma em miseráveis quartos de hotéis. Os circuitos intelectuais franceses eram solidários com os exilados, 
mas quase sempre a solidariedade se atinha ao limite de eventuais encomendas de trabalhos para algum jornal ou revista - tudo se restringia a conversas em bares ou um casual almoço. O fato é que os intelectuais franceses não adotaram os intelectuais exilados. Esses, do bar para fora, viviam na mais abjeta solidão e miséria. Refere-se a condições que poderiam aqui ser descritas com os inúmeros exemplos que Lottman apresenta no seu livro, mas destaco apenas um: a trajetória de Manès Sperber, um escritor judeu, nascido em Zabolotiv, na Galícia austríaca (hoje território ucraniano), exilado em Paris e grande amigo de Goldmann. Manès Sperber, além de escritor, era também um notável articulador da comunidade parisiense de intelectuais refugiados e/ou exilados voluntariamente, prática que o levou a relacionar-se com alguns dos grandes nomes da intelligentsia francesa ${ }^{10}$. Num dia do inverno de 1938, Sperber, que morava num pequeno quarto de hotel sem qualquer calefação, foi convidado por André Malraux para passar na sua casa e ser apresentado a André Gide e Paul Nizan. Gide era o mais importante escritor francês da época, com uma obra literária que tinha repercussões mundiais. Recebido por Malraux, Gide e Nizan, Sperber, diante do calor da lareira e do copo de conhaque que tomou logo ao início da conversa, adormeceu quando Gide falava. "Que alguém pudesse dormir no seu primeiro encontro com André Gide era inimaginável naquele tempo", escreveu Malraux nas suas memórias (apud LOTTMAN, 1987: 50).

Com o início da guerra em 1939, Lucien Goldmann apresentou-se como voluntário ao serviço militar francês, mas não foi aceito por problemas de saúde. Com os nazistas dividindo o controle do país (Paris era a sede do governo de ocupação) com o governo colaboracionista do Marechal Philippe Pétain (governando a partir de Vichy) e temendo uma prisão e deportação,

\footnotetext{
${ }^{10}$ Em Paris, Sperber participou da organização da Associação de Escritores Alemães no Exílio e foi amigo de André Malraux e André Gide, os dois nomes mais importantes das letras francesas do período. Sperber trazia consigo grande experiência intelectual adquirida quando trabalhou em Viena com o psicanalista austríaco Alfred Adler, irmão de Max Adler. Tal detalhe o fez estar próximo de Goldmann. Junto com Arthur Koestler, exilado húngaro, Sperber debateu publicamente sobre os destinos da URSS de Stálin diante dos famosos expurgos políticos que vitimaram, entre muitos, Nicolai Bukharin. Sobre o julgamento e o assassinato de Bukharin por Stálin, Koestler publicou em 1940 um dos seus mais importantes romances: $O$ zero e o infinito. Sobre a trajetória de Manès Sperber consultar o livro de Lottman (1987).
} 
tendo em vista a sua condição de judeu exilado, Goldmann foge para Toulouse. Joseph Gabel acompanhou-o nessa fuga. A situação para os judeus exilados em França ficaria bastante agravada quando o governo Pétain editou em outubro de 1940 o Estatuto Judaico ${ }^{11}$.

Toulouse, em 1940, era ainda uma zona desocupada. Ali Goldmann sobreviveu economicamente continuando a escrever monografias para estudantes ricos e residindo nas instalações estudantis da cidade universitária da Universidade de Toulouse. Nessa Universidade segue com os estudos sobre a filosofia de Kant e ali descobriu também a importância da filosofia de Blaise Pascal e do teatro de Jean Racine para a formulação da "visão trágica de mundo" que já elaborava junto à obra de Kant. Em Toulouse conheceu e apaixonou-se por Madeleine Duclos. Com ela discutiu o seu projeto de estudo sobre Kant visando construir uma crítica marxista sistemática às vulgarizações neokantianas tão em voga na Alemanha e na França. Quando soube do tratado de não agressão assinado por Stálin e Hitler em 1939, Goldmann renunciou qualquer apoio à política do Partido Comunista Francês (PCF). Conversou muito com Madeleine Duclos sobre essas opções, mas sendo ela ativa uma militante comunista abandonou Goldmann para se casar um dos chefes do PCF de Toulouse. Goldmann dedicou-lhe o seu primeiro livro, escrevendo que provavelmente aquele livro sobre Kant tenha sido o "único fruto real do nosso relacionamento" (COHEN, 1994: 43). O livro era uma crítica contundente à distopia stalinista que derrotava o legado fundamental do marxismo: a permanente aposta anticapitalista da luta por uma autêntica comunidade humana.

Diante da repressão do antissemitismo cada vez mais acentuada, em meados de 1942, Goldmann foge outra vez, agora para a cidade de Lyon e de lá, com a ajuda de um comitê de refugiados, seguiu para Zurique, na Suíça, quando foi capturado e preso por vários meses no campo de concentração de

\footnotetext{
${ }^{11}$ Com esse decreto, o governo de Vichy revogou a naturalização de milhares de judeus que tinham obtido a cidadania francesa a partir de 1927. Também revogou a cidadania francesa concedida a judeus argelinos desde 1870 (!) e uma lei nacional de 1939 que proibia o "incitamento ao ódio e à discriminação". Com isso, o governo autorizava a caça aos judeus como um programa de Estado (RIDING, 2014: 78-79).
} 
Gierenbad, localizado a trinta quilômetros de Zurique. Em Gierenbad, Goldmann reencontrou-se com Manès Sperber, que lhe apresentou a obra de Georg Lukács. Essa descoberta de Lukács foi decisiva para a carreira de Goldmann, que depois se fez conhecido como um marxista lukacsiano. Manès Sperber fez entrar no campo de concentração uma cópia do livro História e consciência de classe (1923) de Georg Lukács (2003), livro que foi estudado e debatido nos meses em que estiveram presos (COHEN, 1994). Foi com a leitura e esses debates que Goldmann definiu a sua "ortodoxia” junto ao "marxismo heterodoxo" que Lukács apresentou nesse livro, heterodoxia que depois Lukács abjurou a partir de 1930, quando do seu exílio na URSS stalinista.

Com a ajuda de Tsvi Taubes, antigo rabino de Viena e que no exílio estava como rabino-chefe de Zurique, Goldmann foi libertado do campo de concentração. O filho de Tsvi Taubes, que depois se tornaria um dos mais importantes sociólogos da religião na França e na Alemanha, Jacob Taubes, tornou-se grande amigo de Goldmann em Zurique. Com a ajuda da família Taubes inscreveu-se no curso de Filosofia na Universidade de Zurique para desenvolver uma tese de doutorado sobre a obra de Emmanuel Kant. O filósofo Karl Dürr foi o seu orientador, mas, nesse período de estudos fecundos (de 1943 a 1945), Goldmann encontrou no professor Theophil Spoerri, um especialista na filosofia moderna e estudioso da obra de Pascal, o seu grande interlocutor. Foi ele quem o introduziu à problemática do conceito de tragédia no pensamento moderno, aspecto decisivo para a definição do conceito goldmanniano de pensamento trágico como elemento precursor do pensamento dialético (COHEN, 1994). Goldmann dedicou a publicação da sua tese sobre Kant (terminada em 1944) em livro a Spoerri ${ }^{12}$ e a Madeleine Duclos. Aos 32 anos, depois de um dificílimo percurso, enfim, Goldmann tem o seu primeiro livro publicado, editado em alemão pela Europa Verlag de Zurique, a famosa editora de Emil Oprech, um dos grandes editores europeus nas décadas de 1930 e 1940 (foi editor da obra de Ernst Bloch, Heinrich Mann entre outros). Melhor

\footnotetext{
${ }^{12}$ Goldmann renderá outra homenagem a Spoerri, numa rápida menção que lhe faz no livro Ciências Humanas e Filosofia (GOLDMANN, 1980 [1952, 1ª. edição em francês]), quando o cita referindo-se a Blaise Pascal.
} 
estreia, impossível. Em 1948, Goldmann publicou o livro em francês, num momento em que já trabalhava em Paris na sua pesquisa sobre a filosofia de Blaise Pascal e o teatro de Jean Racine. A edição francesa saiu chancelada por Félix Alcan, um dos proprietários da Presses Universitaires de France (PUF), então a maior e mais importante editora universitária da França. A publicação do livro em francês deu-lhe prestígio acadêmico e condições institucionais de pesquisa e docência.

Enquanto preparava sua tese de doutorado, em 1943, Goldmann foi a Genebra para encontrar-se com Jean Piaget, o pensador suíço que viria a ser reconhecido nas décadas seguintes como um dos grandes pensadores do século XX. O modelo piagetiano da epistemologia genética teve grande impacto nas perspectivas goldmannianas de construção de uma história do pensamento dialético iniciada com Kant e que seguiria depois com Pascal e Racine e planejada para continuar com estudos sobre Goethe, Marx e Lukács. Goldmann sabia dos trabalhos sobre teoria do conhecimento que Piaget apresentara em 1942 numa série de conferências na Universidade de Paris e via-o como um pensador dialético de grande magnitude, ainda que não marxista. Ao longo das décadas de 1950 e 1960 houve um profícuo diálogo entre os dois ${ }^{13}$. Num dos artigos que Goldmann dedicou a Piaget, em trecho que transcrevo a seguir, é possível depreender a importância e o alcance da obra de Piaget para a filosofia em geral e a sua proximidade com o pensamento dialético marxista, que, além da importante descrição teórico-metodológica que sintetiza, traduz a importância da obra piagetiana para a obra goldmanniana.

[...] Piaget propõe-nos uma inversão completa da classificação das ciências. Desde Auguste Comte que a maior

\footnotetext{
${ }^{13}$ Goldmann escreveu alguns artigos sobre a epistemologia genética de Piaget. Entre outros, cite-se o artigo "Jean Piaget e a filosofia" (1966), traduzido e publicado como capítulo no livro de Goldmann (1984: 41-61). Jean Piaget faz referência à obra de Goldmann num dos seus livros mais importantes - Sabedoria e ilusões da Filosofia (ver: PIAGET, 1978: 112). Afirma o autor: "Piaget não é por certo marxista e a confirmação ou infirmação do pensamento de Marx é a última das suas preocupações. Este fato aumenta, contudo, a importância filosófica dos seus trabalhos. Com efeito nada confirma melhor o valor de uma concepção do que o encontro de pensadores que vêm de pontos diferentes e que ignoram, cada um deles, os passos e os trabalhos dos outros" (GOLDMANN, 1984: 44). Note o leitor que Goldmann remete as conclusões sugeridas pela obra de Karl Marx como termo equivalente àquelas apresentadas pela obra de Jean Piaget.
} 
parte das classificações tinha um caráter linear e, intencionalmente ou não, iam ao encontro da ideia cartesiana de que a marcha natural e eficaz da razão é partir do simples para o complexo, da parte para o todo. A crítica de Piaget junta-se neste plano às críticas de Pascal contra a epistemologia e o método cartesianos, às de Kant contra a monadologia de Leibniz e às de Hegel e de Marx contra o empirismo e o racionalismo em geral. Para estes pensadores não há nem partes autônomas, nem princípios primeiros. Qualquer parte existe pelas suas relações com as outras partes no conjunto, e o pensamento científico que quer compreender a realidade deve avançar por deslocações permanentes entre o conjunto e as partes. (GOLDMANN, 1987: 51).

Trinta anos depois do encontro em Genebra, a Universidade de Bruxelas promoveu em 1973 um colóquio em homenagem à obra e trajetória de Lucien Goldmann. Nessa ocasião, Jean Piaget apresentou um depoimento sobre a sua relação e admiração intelectual para com Goldmann. Segundo Piaget, a obra de Goldmann representava uma revolução conceitual de máxima importância para a sociologia dos estudos simbólicos do século XX, principalmente pelo que apresentou nos estudos dedicados a Kant e a Pascal. Ainda nesse depoimento, descrevendo o primeiro contato que tiveram, Jean Piaget narra que, em certo dia do ano de 1943, ele apareceu-lhe em casa declarando que queria trabalhar com ele e que, em sendo marxista, via nele, Piaget, o pensador dialético mais autêntico do Ocidente e que ele (Goldmann), mesmo não tendo ainda publicado nada de expressivo (em 1943), tinha vários projetos em mente e que entre esses estava um estudo dedicado à sua obra. Conta Piaget que se viu "amedrontado" com tais perspectivas e que de imediato disse a Goldmann que ele nunca tinha lido uma linha de Marx ou de qualquer outro teórico marxista e que tampouco tinha qualquer intenção de o fazer. Goldmann respondeu-lhe que essa era então a situação ideal e que, diante das tantas deformações que vinha sofrendo o marxismo, ele lhe explicaria os seus significados evitando tais deformações (COHEN, 1994). Trinta anos depois, Piaget estava num evento homenageando o amigo marxista. Se Goldman encontrou em Piaget uma expressão dialética de máxima importância, Piaget encontrou em Goldmann um pensador que muito o ajudou a formular as suas perspectivas teóricas. É importante ressalvar esse 
detalhe, para que se perceba a heterodoxia goldmanniana na busca de aportes e ferramentas originais para manter sempre criativo o seu diálogo com as matrizes marxistas que lhe eram estruturantes: Marx e Lukács.

\section{As primeiras publicações do pensador marxista outsider (1948-1952)}

Com a publicação em alemão e em francês do seu estudo sobre Kant, Lucien Goldman assume o status de pensador original no campo dos revisionismos marxistas do após-guerra e sua trajetória assume um protagonismo institucional inédito. Nesse sentido, diferentemente da forma como foram apresentados até aqui, os fatos a serem narrados para a descrição analítica do seu percurso como pensador marxista de larga interlocução institucional contarão, doravante, com a mediação dos debates teórico-políticos nos quais esteve envolvido. Por conseguinte, seu percurso será agora descrito em grande parte pelos escritos que publicou diante das polêmicas teóricopolíticas que o envolveram. A descrição biográfico-institucional ficará agora subsumida, na sua exposição a essa descrição analítico-conceitual da obra que Goldmann publicou de 1948 a 1952. E começo descrevendo o seu livro de estreia.

O que efetivamente quis apresentar Lucien Goldmann com seu estudo sobre a filosofia de Kant? Qual a aposta teórico-filosófica, qual a aposta política apresentada pelo livro?

Afirma Goldmann (1967b: 7) que o propósito do livro era o de fornecer uma introdução à filosofia de Kant, mais precisamente, "um estudo sobre o homem e a comunidade humana no pensamento de Kant". O livro é uma introdução política à filosofia de Kant, pois a análise sistematizada da kantiana, nele desenvolvida, apresentou-se em confronto com algumas correntes da filosofia neokantiana, principalmente aquela das grandes universidades alemãs reiteradoras, inicialmente, do projeto tecnocrático bismarckiano e que após 1920 passaram a escudar perspectivas filosóficas intuicionistas (Scheller e Bergson, por exemplo) cujo irracionalismo, na perspectiva goldmanniana, 
andava quase no limite ideológico de apoio aos fascismos históricos. E, segundo Goldmann, essas práticas institucionais autorreferenciadas como neokantianas derrotavam o projeto original de Kant. Com o livro, Goldmann apostava na defesa de um Kant há muito ausente na cultura neokantiana contemporânea, cultura essa que reiterava o Kant do positivismo e irracionalismo das Escolas de Marburg e de Heidelberg. Defendendo o Kant que foi resgatado em Viena com o marxismo de Max Adler e politicamente derrotado pelos fascismos, Goldmann encontra na obra do filósofo prussiano um pensador trágico no limite do seu pensamento intrinsecamente dialético. Resgatar a autenticidade do pensamento kantiano naquela conjuntura da Segunda Guerra Mundial era uma forma concreta de combate aos fascismos e às suas ideologias irracionalistas. Numa passagem importante do livro, Goldmann define com precisão o sentido do seu trabalho. Numa nota de rodapé, ao definir como critério de "verdade histórica" a ação e a prática dos indivíduos socialmente constituídos, afirma que:

[...] numa sociedade onde não é a comunidade, o Nós, mas o indivíduo, isto é, o Eu, que constitui o sujeito da ação, o critério de verdade não pode ser senão individual, isto é, o $\mathrm{Eu}$, que constitui o sujeito da ação, o critério de verdade não pode ser senão individual e não pode ter valor universal. $\mathrm{Na}$ medida em que grupos limitados (classes, povos, etc.) constituem o sujeito da ação, formam-se ideologias de classe e ideologias nacionais que podem ser verdadeiras ou falsas segundo têm ou não a humanidade inteira como fim. (GOLDMANN, 1967b: 167, grifo nosso).

O critério da universalidade da comunidade humana (o "Nós" como sujeito da ação histórica que assim se define pelo projeto político, pela aposta com o futuro dessa humanidade) dá o sentido geral que Goldmann encontra com a obra de Kant. A universalidade da perspectiva da totalidade mediada pela visão de mundo do proletariado que o autor desenvolve como sua premissa teórico-metodológica resulta da sua experiência intelectual de juventude junto ao marxismo adleriano e, depois, junto ao argumento central do marxismo lukacsiano de 1923, apresentado no livro História e consciência de classe (HCC). E é necessário endossar que, para Goldmann, o Georg Lukács de 1923 
se afirmava como resultado filosófico da institucionalização histórica do pensamento dialético universal nascido das experiências filosóficas (trágicodialéticas ${ }^{14}$ ) de Pascal e Kant e depois asseveradas como dialética concreta com Hegel e Marx. Com o livro de 1923 - História e consciência de classe -, Georg Lukács colocou-se no século XX como a máxima expressão filosófica da tradição dialética de estudos hegeliano-marxistas ${ }^{15}$. Lucien Goldmann sempre defendeu essa obra como a mais importante do marxismo no século XX e o fazia quase sempre contrariando a própria opinião de Lukács, que renunciara essa publicação no começo da década de 1930, apresentando-a como um livro idealista. Lukács, a acreditar no que afirma Mitchell Cohen (1994), nunca teve uma relação fraternal com Goldmann, que, se não era alvo de ironias de Lukács com seus alunos, penso que em ao menos duas oportunidades foi alvo de humilhações. A primeira por meio de uma carta que o filósofo húngaro escreveu a Goldmann datada de $1^{\circ}$ de outubro de 1959 , que transcrevo a seguir:

Se eu estivesse morto por volta de 1924, e se minha alma imutável tivesse olhado vossa atividade literária do além, estaria plena de um verdadeiro reconhecimento por ocuparvos tão intensamente com minhas obras de juventude. Mas, como não estou morto e, durante trinta e quatro anos, criei o que deve chamar-se de a obra da minha vida e como, em suma, para vós, essa obra não existe de forma alguma, é difícil para mim, como ser vivo, cujos interesses são dirigidos, evidentemente, para sua própria atividade presente, levar em conta vossas considerações. (Apud TERTULIAN, 2008: 292).

A outra humilhação deu-se com Goldmann já falecido. Num evento dedicado à memória e à obra de Goldmann no começo de 1971 (Goldmann

\footnotetext{
${ }^{14}$ Utilizo-me do termo "trágico-dialéticas" para descrever o sentido processual do pensamento dialético em potência percebida, mas ainda não afirmada socialmente, da obra de Pascal e Kant, como inauguradores do pensamento dialético sob perspectiva concreta da totalidade histórica, sugerida inicialmente por Spinoza e depois descrita e demonstrada por Hegel e Marx. Se para Goldmann as obras e trajetórias de Pascal e Kant afirmavam a totalidade histórica sob impossibilidade social percebida (daí serem a expressão máxima da "visão trágica de mundo"), uso o termo "trágico-dialéticas" para operacionalizar o sentido historiográfico da minha descrição analítica, enfim, um termo formalmente retórico, mas eivado de sentido processual derivado da perspectiva metodológica goldmanniana.

${ }^{15}$ Goldmann escreveu vários artigos sobre Lukács. Michael Löwy (1990: 111-129) apresenta esses estudos de Goldmann sobre Lukács num belíssimo ensaio intitulado "Goldmann e Lukács: a visão trágica de mundo".
} 
faleceu em novembro de 1970), em que Jean Piaget também esteve presente com um depoimento e para o qual Lukács também foi convidado, este ausentou-se, enviando para os organizadores do encontro um texto de sua autoria (escrito em 1910) para ser traduzido para o francês, já que, segundo disse, Goldmann apreciava muito aquele trabalho de juventude (COHEN, 1994). Cohen (1994) interpretou o gesto como um "ato de gratidão" de Lukács, mas penso que não. Se não foi um ato de terrível ironia ou humilhação, foi um ato de profundo narcisismo, afinal o filósofo húngaro, além de não se referir à obra ou tampouco ao percurso de Goldmann, enviou aos organizadores do evento um pedido de tradução para o francês de um artigo seu e ainda por cima da sua fase kantiana!

Enfim, com origens na corrente neokantiana do marxismo adleriano (que lhe substantiva a práxis conselhista) e mobilizado conceitualmente pelo marxismo lukacsiano (da obra de 1923, repito), Goldmann desenvolverá uma interpretação da kantiana com o propósito de lhe resgatar uma estrutura intrínseca amplamente esquecida pelas demais correntes neokantianas: a dialética da permanente aposta na comunidade humana do futuro! O Kant de Goldmann é um precursor trágico do pensamento dialético hegeliano-marxista, muito diferente do Kant positivista e/ou liberal intuicionista tal como era consorciado pelas escolas neokantianas das tecnocracias capitalistas que lhe eram contemporâneas. Goldmann terminou de escrever a tese três meses após a vitória dos aliados na Normandia (em 6 de junho de 1944). Nesse sentido, tem razão Mitchell Cohen (1994: 44) quando diz que a tese/livro "irradiava esperança", um trabalho realizado em circunstâncias de desespero que soube como nenhum outro perceber a condição trágica da aposta intelectual na comunidade humana do futuro. A seguir faço uma descrição de alguns tópicos do livro, ressalvando o debate de Goldmann com as correntes neokantianas contemporâneas, para assim apresentar, numa primeira síntese descritiva, a estrutura conceitual e a operacionalidade do marxismo do autor.

Goldmann não apresenta Kant como um teórico da epistemologia ou como um filósofo tradicional da tradição clássica do Ocidente. Muito ao 
contrário, trabalha com a sua epistemologia e filosofia sistemática para definir o pensador prussiano como o mais profundo e avançado pensador da cultura individualista da burguesia clássica. $\mathrm{O}$ grande pensador da cultura burguesa percebido em situação trágica, porque notava os limites históricos dessa cultura e vislumbrava as possibilidades do seu esgarçamento, mas ainda sem condições de poder ultrapassar e efetivar (GOLDMANN, 1967b). Kant, com a sua obra, nas últimas décadas do século XVIII, apresentava aos seus contemporâneos os fundamentos de uma nova estrutura filosófica centrada nos conceitos de Universo, de Totalidade, assinalando, assim, os fundamentos da moderna filosofia dialética. Segundo Goldmann, na filosofia ocidental, Kant era a expressão do máximo de consciência possível ${ }^{16}$ da filosofia burguesa alemã e que por causa disso era também a expressão máxima das contradições que tal sistema filosófico (ideológico) evidenciava, porque ao explorar os limites e mesmo as contradições do individualismo racionalista burguês (basta verificar a tese da sociabilidade-insociável na sua imanência derrotando a perspectiva totalizante da comunidade humana como termo antípoda dessa imanência) já esboçava, indicava e sugeria a necessidade da sua superação. Esta era a condição trágica do pensamento kantiano: perceber os limites do mundo, saber da necessidade de os superar, mas sem encontrar as possibilidades de ato, a comunidade humana como um a priori utópico. O individualismo burguês estava caracterizado pela "sociabilidade-associal" ou "sociabilidadeinsociável", isto é, a ação histórica do homem burguês que obrigatoriamente o leva à condição de ser social, mas determinado ideologicamente pela contradição da racionalidade do individualismo que o coloca em cena social sob práticas concorrenciais individualistas mediadas pela cultura do liberalismo: o racionalismo dos indivíduos separados no conjunto da sociedade. Afirma Goldmann que a obra de Kant tem uma perspectiva filosófica "emanentista" (ou

\footnotetext{
${ }^{16}$ O termo "máximo de consciência possível” percorre toda a obra de Lucien Goldmann e está derivado como conceito das definições de "consciência real" e "consciência possível" que Lukács desenvolveu no livro História e consciência de classe. Adiante volto a essa definição. Por ora, cumpre sumariar o termo dizendo que a consciência possível indica a posição de vanguarda do pensador perante o seu grupo ou classe social, significa que as possibilidades desse grupo/classe estão indicadas para além do senso comum do pensamento imediato, empírico, para além, portanto, da "consciência real".
} 
panteísta), com a natureza e a comunidade definidas como expressão da totalidade histórica. "O ponto de vista emanentista vê no todo, na totalidade, a condição necessária da existência das partes e dos indivíduos" (GOLDMANN, 1967b: 50) e essa definição contrasta com a do pensamento analítico (que normalmente está imputado a Kant pela tradição neokantiana) que Goldmann define como uma perspectiva que vê nos indivíduos "a única realidade autêntica", com uma "existência independente do conjunto", mediados os seus atributos sociais principalmente por "leis lógicas e morais". Ao contrário dessa assertiva, Goldmann afirma que a filosofia de Kant caracteriza o pensamento não como parte intrínseca do indivíduo em sociedade, mas como um efeito da sociedade ao indivíduo, termo que o leva à conclusão de ser o universo uma totalidade de possibilidades. Afirmou Kant: "Se o conceito de Universo significasse o conjunto das coisas possíveis, a saber, que são possíveis em sua relação com a causa universal, seria mais fecundo" (apud GOLDMANN, 1967b: 51, grifo no original).

Do conjunto da obra do filósofo alemão, Goldmann (1967b: 89) encontra no livro de 1759 - Divagações de um visionário - uma expressão "infinitamente superior a muitas outras obras filosóficas escritas depois". Essa conclusão contrastava em muito com as leituras neokantianas que lhe eram contemporâneas e que endossavam fundamentalmente as três Críticas - Crítica da razão pura (1781); Crítica da razão prática (1788); e Crítica do juízo (1790); e além disso endossa a perspectiva do autor, que em análise metodológica relacional comparada do conjunto da obra depreende dessa operação as "estruturas significativas"17 sobre as quais estaria construído o sentido do pensamento kantiano.

${ }^{17}$ O termo "estruturas significativas" é de máxima importância no marxismo goldmanniano e
está presente como perspectiva metodológica na integralidade dos estudos de Goldmann. Num
pequeno ensaio publicado em 1958 - "O conceito de estrutura significativa na História da
Cultura", Goldmann (1979: 94) cita Jean Piaget para definir o conceito de estrutura: "Diremos
em primeiro lugar que há estrutura (em seu aspecto mais geral) quando os elementos estão
reunidos numa totalidade, apresentando algumas propriedades como totalidade e quando as
propriedades dos elementos dependem, total ou parcialmente, dessas características da
totalidade". E dessa referência a Piaget, o autor deriva uma série importantíssima de conclusões
teórico-metodológicas nos estudos de História da Cultura. Dentre as apresentadas, destaco esta:
para escolher "na realidade um conjunto de fatos que constituem tal estrutura significativa, e 
Na primeira parte do livro, Goldmann trabalha com o conjunto de textos que Kant publicara até 1770 , a chamada "fase pré-crítica". Nesses textos a questão da totalidade era a estrutura significativa central do sistema kantiano, o "sistema transcendental", porque em grande parte Kant dialogava com a tradição dos racionalistas dogmáticos e todos eles admitiam a questão da totalidade como o dado estruturador da realidade. Kant só voltaria a publicar novamente no ano de 1781, quando aparece o livro Crítica da razão pura, a primeira das três Críticas, as obras magnas do autor. Kant, ao longo da década de 1770, deparou-se com a obra de David Hume. O diálogo com o empirismo de Hume foi de fundamental importância para a definição das Críticas. Que problemas apresentava Hume perante a perspectiva kantiana já desenvolvida? Hume e os empiristas tinham uma tese que confrontava a essência do modelo kantiano: Hume negava a existência e a possibilidade de qualquer totalidade! Kant foi obrigado, diante dos argumentos do empirismo, a fazer modificações no seu sistema filosófico. Escreve Goldmann que Kant, no período pré-crítico, dado o fato de todos os seus oponentes filosóficos não porem em dúvida a existência da totalidade como ponto de partida, com Hume o argumento mudava radicalmente e, grave, se o empirismo humeano negava a possibilidade da totalidade como existência teórica e prática, o sistema kantiano estava afetivamente ameaçado. O longo período que antecedeu a publicação da Crítica da razão pura em 1781 foi dedicado ao estudo das proposições de David Hume, autor que na expressão clássica "despertou Kant do seu sono dogmático". Kant critica Hume, mas fazendo-lhe concessões. Escreve Goldmann (1967b: 104, grifo no original) que Kant passa a renunciar "a qualquer totalidade dada, existindo fora de nós que o homem não pôde criar, mas somente conhecer. Eis aí a influência decisiva de Hume sobre Kant”. Do diálogo de Kant com Hume, apresenta estas conclusões: “A realidade, o dado, não é então atomístico, constitui uma totalidade (ao menos formal, se não é

para separar no dado empírico bruto o essencial do acidental, é indispensável inserir esses fatos ainda mal conhecidos numa outra estrutura mais ampla que os abarca, sem jamais esquecer que os conhecimentos provisórios que se têm dos fatos dos quais se partiu são - precisamente na medida em que se constituem um elemento da estrutura mais ampla - um dos pontos de apoio mais importantes para deduzir esta última" (GOLDMANN, 1979: 101). 
material e perfeita)" - daí que as "sensações são dadas no todo espacial e temporal. Há uma intuição pura" e isso leva Kant a afirmar que ao filósofo restava "deduzir da necessidade de uma experiência anteriormente reconhecida como possível o caráter a priori das categorias em geral e da causalidade em particular" (apud GOLDMANN, 1967b: 106-107). Em rápida descrição, nesses termos se define a dialética do sistema transcendental kantiano ${ }^{18}$.

Afirma o autor que, no seu sentido geral, a obra de Emmanuel Kant "abriu caminho para uma filosofia nova" porque sintetizava a "ideia cristã da limitação do homem com a imanência dos pensadores da antiguidade" e com as imanências dos pensadores dos séculos XVII e XVIII, ${ }^{19}$ concebendo nessa síntese um "mundo inteligível", tendo a totalidade como uma tarefa humana, a totalidade como "objeto do destino autêntico do homem e produto de sua ação" (GOLDMANN, 1967b: 250). Kant criou, "pela primeira vez, a possibilidade de uma filosofia baseada na ideia da comunidade e da pessoa humana, quer dizer", uma "filosofia da história" (GOLDMANN, 1967b: 250). Assim, Goldmann (1967b: 254) justifica o sentido político do seu livro escrito durante a guerra:

Nossos olhares não devem voltar para trás, para procurar um retorno a Kant, mas para a frente, na direção de uma comunidade humana melhor; e é assim que podemos ver a figura de Emanuel Kant em sua verdadeira luz, em sua verdadeira importância ainda vivo e real para o presente e para o futuro. Ele nos aparecerá, então, como um dos grandes pensadores que deram os primeiros passos difíceis no meio das pedras e abriram o caminho no qual estamos marchando.

\footnotetext{
${ }^{18}$ Goldmann complementa: "A ideia de que o destino autêntico do homem é o de se dirigir para o absoluto, quer dizer, para qualquer coisa completamente diferente do dado empírico [...]. Já que o homem só pode progredir na direção do absoluto através das sensações dadas e apesar das inclinações de seus sentidos, deve criar o máximo daquilo que lhe é acessível, quer dizer, a) teoricamente, um conhecimento experimental coerente e, b) praticamente, uma vida conforme ao imperativo categórico" (GOLDMANN, 1967b: 110, 111).

${ }^{19}$ Leibniz, Malebranche, Spinoza e Descartes são os nomes, na fase pré-crítica, com quem Kant dialogava. Depois aparece-lhe David Hume. Com Hume o "sistema transcendental" estava ameaçado e para se justificar precisava antes de tudo refutar a tese empirista "de que o dado empírico é a única fonte legítima e verdadeira do conhecimento" (GOLDMANN, 1967b: 104). Kant percebeu que tomava direções equivocadas antes de se deparar com a obra de Hume e contra o empirismo redutor tinha de manter e defender a perspectiva da totalidade, mas agora numa direção correta, qual seja: a totalidade percebida como não exterior ao homem, mas existindo nele, mas não como algo já dado, existindo como potência humana, como "o fim supremo que dá ao homem sua dignidade de homem". A totalidade "é a ideia transcendental", um "postulado prático" (GOLDMANN, 1967b: 104).
} 
Depois da descrição do modelo e de ressalvar a estrutura significativa mais importante, isto é, Kant e a perspectiva da totalidade, termo que dá ao livro essa característica de vínculo com o modelo interpretativo lukacsiano, Goldmann passa a apresentar as reais dimensões políticas do seu livro: o combate ao que definia como os "irracionalismos da tradição neokantiana", especialmente, como já afirmado, o das escolas neokantianas de Marburg e Heidelberg, que, em posição contundente, o autor via como amplamente equivocadas nas leituras apresentadas sobre a obra de Kant. Afirma no livro (1967: 108) que as experiências filosóficas do neokantismo de 1870 a 1920 foram um grande "mal-entendido". Numa sequência brilhante de páginas de análise historiográfica, Goldmann dimensiona o sentido geral da obra de Kant quando estava em processo de elaboração, para, logo após, desenvolver uma análise histórico-institucional das apropriações dessa obra pelos neokantianos no momento de organização do Estado nacional alemão, no Reich de Bismarck, a partir de 1870.

Na segunda metade do século XVIII, momento em que Kant vivia em Konisgberg (Prússia Oriental) ${ }^{20}$, a "Alemanha" (que inexistia como país) estava muito atrasada economicamente, visto que, na ausência de um Estado nacional, o desenvolvimento social e político era bastante precário. Contudo, esse "caráter patológico" das contradições do atraso do "corpo social" capitalista em formação é que permitia "aos elementos progressistas da burguesia alemã atingir um conhecimento filosófico muito mais claro e mais profundo do que no resto da Europa" (GOLDMANN, 1967b: 109-110). Diante do "racionalismo otimista dos franceses, podia-se opor na Alemanha uma visão clara das insuficiências reais da ordem social burguesa e individualista que estava em vias de nascer na Europa" (GOLDMANN, 1967b: 110). A realidade vivida na Alemanha era bastante insatisfatória se comparada também com a da Inglaterra dos empiristas. Conclui o autor que, diante do quadro comparado, a obra de Kant apostava num "futuro melhor" e exigia do pensador "projetar-se para ele" (o futuro) e isso com todas as forças e beleza da imaginação, a aposta num

\footnotetext{
${ }^{20}$ Atualmente é a cidade russa de Kaliningrado.
} 
futuro ainda "mais perfeito do que a ordem existente na Inglaterra ou em vias de nascer na França" (GOLDMANN, 1967b: 110) ${ }^{21}$.

A Alemanha capitalista define-se como nação com a unificação promovida em 1870 por Bismarck e em pouco tempo o país tornou-se uma potência econômica para além de Inglaterra e França e o pensamento de Kant esteve presente nesse processo, mas de um modo, diz Goldmann, que vulgarizava em muito o seu pensamento. Com a unificação nacional, escolas e revistas dedicadas à obra de Kant transformariam em definitivo a Alemanha também numa potência filosófica, e as escolas de Marburg e a de Heidelberg, junto com as revistas Kantstudien e a Logos, eram a expressão institucional do movimento de ideias conhecido como "neokantiano". Mas, diz Goldmann (1967b: 108), de 1870 a 1920 o movimento filosófico neokantiano tornou-se na verdade um "grande mal-entendido" sobre a obra de Kant.

A Alemanha unificada em pouco tempo ultrapassou industrialmente as principais potências capitalistas do Ocidente; entretanto, essa revolução capitalista nacional deu-se com a ausência de um "espírito liberal análogo ao da burguesa francesa e inglesa". Diz Goldmann que a burguesia alemã não adquiriu o Estado com as suas próprias forças: "recebeu-o como um dom da classe dirigente, a nobreza e os fidalgos rurais", de modo que o Reich alemão foi criado em movimento de elites não burguesas. "À nobreza rural tinham sido reservadas as posições importantes e, antes de tudo, os corpos de oficiais e da diplomacia”. A burguesia subserviente aprendeu a servir o establishment e alguns grandes industriais acabaram por se tornar importantes figuras de Estado. Foi o caso, por exemplo, do industrial Walther Rathenau. Mas, afirma Goldmann (1967b: 112): “nunca a burguesia alemã conseguiu apoderar-se do aparelho de Estado e democratizá-lo. Nem mesmo no período mais radical, durante os governos mais ou menos socialistas dos anos após 1918”. Um

\footnotetext{
21 "A ideia de que o homem empiricamente dado (que, para Kant, é o homem em geral) depende de algo exterior (a sensibilidade), que o limita e o impede de atingir o absoluto. Na análise dessa limitação do homem, Kant estabelece os fundamentos filosóficos de uma crítica tão aguda quanto possivel da sociedade burguesa e individualista. Tudo o que veio depois dele (Hegel e Marx - João Alberto) só fez desenvolver essa análise e aplicá-la nos diferentes setores" (GOLDMANN, 1967b: 110, grifo nosso).
} 
fenômeno acentuou-se na experiência histórica do capitalismo alemão: a rápida adaptação às "mais avançadas técnicas" e foi desse modo que surgiu o especialista, o gestor: "técnico eminente em seu ramo, organizador perfeito, disciplinado ao extremo, obedecendo sempre os superiores, duro com os subalternos, carente de um horizonte" mais aberto, liberal (GOLDMANN, 1967b: 112). Depois de 1870, a Alemanha patrocinou a existência dos mais eruditos "professores de filosofia do mundo", mas perdendo inteiramente o seu espírito filosófico, um pragmatismo institucional que transformava filósofos em especialistas eruditos, sem originalidade alguma. Goldmann lembra que Marx e Nietzsche, os "últimos grandes filósofos alemães", o eram por viverem no estrangeiro. Desse pragmatismo definiu-se o movimento neokantiano, que se tornou a filosofia dessa época e, na conclusão-chave de Goldmann, esse retorno a Kant anulava Kant. "O que em Kant era consciência de uma limitação trágica do homem tornou-se um fato normal", uma "apologia", fazendo desaparecer o espírito do pensamento de Kant. Conclui Goldmann (1967b: 113) que na escola de Marburg "preferiu-se suprimir a dialética provando-se que o importante eram os 'conceitos-limites'; em Heidelberg a dialética era apresentada como uma sobrevivência do período dogmático ou um contrassenso". Depois de descrever as teses de alguns neokantianos, como as de Bruno Bauch (de Heidelberg), Goldmann (1967b: 115), ironicamente, sentencia: “tem-se a impressão de que Kant infelizmente viveu muito cedo. Se tivesse escutado pelo menos alguns cursos de Bruno Bauch, teria provavelmente se tornado um verdadeiro filósofo".

Esse livro, por ser o primeiro, não possui ainda uma estrutura de composição que leve ao limite do exemplo a proposta metodológica que Goldmann desenvolveria depois. Trata-se de uma análise interna do conjunto da obra de Kant apresentada no seu quadro cronológico de publicações. Refere-se a um combate político às escolas neokantianas europeias. Da análise do livro depreende-se que a construção historiográfica da kantiana elaborada pelo autor foi definida como expressão do conteúdo de classe da visão de mundo, do máximo de consciência possível de uma burguesia "trágica" na história social 
prussiana (alemã) do fim do século XVIII. Desse modo o livro é uma expressão outsider do marxismo dissidente europeu, primeiro pelo combate travado no terreno dos modelos neokantianos (uma crítica que se fez com base numa interpretação sistemática do conjunto da obra de Kant); e, segundo, como afirmação dissidente no quadro dos marxismos em geral pela reiteração dos princípios metodológicos lukacsianos de História e consciência de classe. Trata-se, de modo inquestionável, do primeiro grande trabalho do marxismo no após Segunda Guerra Mundial a recuperar o livro clássico de Lukács, esquecido e abjurado pelo próprio autor. Com a edição francesa de 1948, Goldmann introduz na cultura historiográfica erudita a matriz do marxismo lukacsiano ou o princípio marxista da totalidade histórica. A originalidade do marxismo goldmanniano foi mundialmente conhecida com a publicação em 1956 do livro O Deus oculto - esse é o trabalho clássico da historiografia goldmanniana. O segundo livro de Goldmann, que foi publicado em 1952, Ciências Humanas e Filosofia $^{22}$, apresenta outra característica no conjunto da obra de Goldmann: os escritos metodológicos. Em 1948 e em 1950, depois de editar o livro sobre Kant em francês, Goldmann publicou dois artigos ${ }^{23}$ sobre questões teóricas referentes ao marxismo. Esses artigos inauguravam uma série de publicações de ensaios e artigos de natureza teórico-metodológica apresentada também em alguns livros que obtiveram grande sucesso e repercussão no debate marxista contemporâneo, como por exemplo Recherches dialectiques ${ }^{24}$, publicado em 1959. A seguir faço uma breve apreciação da estrutura conceitual que Goldmann desenvolveu nos dois artigos e no livro de 1952, e com isso encerro

\footnotetext{
22 O livro foi encomendado a Goldmann pelo filósofo Emile Brehier, que coordenava a Nouvelle Encyclopédie Philosophique para a editora Presses Universitaires de France. O livro de Goldmann era o de número 53 da coleção que contava com nomes de grande prestígio na cultura acadêmica universitária, como Henri Lefebvre, autor do volume 21, de título $O$ materialismo dialético, e Jean Paul Sartre, autor do volume 10, de título A imaginação (GOLDMANN, 1952, informação de contracapa).

23 O artigo "Materialismo dialético e história da filosofia" foi publicado na revista Philosophique de France et de l'ètranger, 1948, n 4-6; e o artigo "Materialismo dialético e história da literatura" foi publicado na revista Métaphisique et Morale, 1950, $\mathrm{n}^{\circ}$ 7-9 (GOLDMANN, 1952). Ambos foram traduzidos no livro Dialética e cultura (GOLDMANN, 1979: 45-89), mas estão remetidos erroneamente à data de 1947.

${ }^{24}$ Esse livro não tem tradução integral em português, mas alguns capítulos foram reunidos no livro Dialética e cultura (GOLDMANN, 1979).
} 
este artigo com um esboço introdutório dos principais matizes do marxismo goldmanniano.

Conclusão: uma síntese dos primeiros escritos de Goldmann (1948-1952)

Apreciados os três trabalhos em conjunto depreendo deles um roteiro categorial/conceitual que em suas linhas gerais procura apontar a originalidade e o alcance metodológico do marxismo goldmanniano. Algumas categorias trabalhadas pelo autor já foram aqui minimamente definidas, caso de "visão de mundo", por exemplo. No livro de 1952 o esforço de Goldmann, dada a natureza de textos introdutórios que marcava a coleção organizada por Émile Bréhier, foi o de sistematizar, para as ciências humanas em geral e para a historiografia da cultura em particular, um argumento marxista estruturado em grande parte na obra de Lukács de 1923. Para justificar a centralidade da dialética marxista no estudo da história da cultura, Goldmann põe à prova o seu método em diálogo direto com as grandes matrizes sociológicas que lhe eram contemporâneas. Dialoga criticamente com a obra de Max Weber, de Emile Durkheim, Georges Gurvitch entre vários outros clássicos, cuja demonstração da prova do seu argumento obriga o autor a exposições-síntese dessas grandes referências das ciências sociais contemporâneas. Nesse sentido, o livro também é uma excelente apresentação didática das mais importantes matrizes sociológicas antípodas ou críticas do marxismo. Um pequeno livro notável de permanente atualidade. E, curiosamente, se considerarmos as últimas páginas, $\mathrm{o}$ livro oferece um apêndice da investigação que Goldmann desenvolvia àquela altura e que se consumaria posteriormente, no ano de 1956, com a publicação da sua obra mais importante: O Deus oculto (Le Dieu caché) (GOLDMANN, 1988). Com a própria pesquisa em movimento, demonstrava a factibilidade do método exposto ao longo do livro, o que torna ainda mais coerente a sua proposta de testar os limites do seu trabalho como marxista, aplicando-lhe as próprias bases teóricas sugeridas como modelo de estudo para o grande público. 
Lucien Goldmann nunca foi um marxista canônico. Pelo contrário, um exemplo da sua heterodoxia era a defesa intransigente da importância de História e consciência de classe feita muitas vezes contra o próprio autor do livro. Penso que a sua originalidade como marxista se deve ao fato de levar ao limite da plausibilidade e coerência a lógica da estrutura argumentativa que manuseava nas suas obras historiográficas ou nas obras metodológicas, quando todas as categorias e conceitos utilizados estão sempre balizados por rigoroso escrutínio com fontes ou em relação comparada com a estrutura conceitual de outras matrizes teoréticas. Por conseguinte, é necessário imaginar o grau de dificuldades que o autor teve de enfrentar tanto no ambiente acadêmico francês (bastante refratário à cultura marxista no imediato após-guerra, pelo menos até meados da década de 1950), como diante da ortodoxia marxista celebrada pelos comunistas franceses junto ao cânone stalinista. Goldmann continuou sendo um "pária”, um "judeu”, nas instituições acadêmicas que percorreu, ao menos entre 1945 e 1956, quando se consagrou com a publicação de $O$ Deus oculto, livro que foi amplamente debatido nas principais revistas acadêmicas de então ${ }^{25}$.

O tema da cultura, da história das ideias, da história dos intelectuais e das suas ideologias atravessa a integralidade da sua obra. Seus escritos metodológicos são uma vigorosa contribuição teórica a esses campos de investigação historiográfica, o que já pudemos demonstrar com a apresentação da tese/livro que escreveu sobre a obra de Kant. Goldmann escreveu, nas décadas seguintes, livros, ensaios e artigos sobre a obra e as trajetórias de Blaise Pascal, Jean Racine, Kant Goethe, Marx, Sartre, Heidegger, Lukács, Malraux, Genet, Allain Robbe-Grillet, Natalie Sarraute, Marc Chagall, entre outros - filósofos, escritores, artistas plásticos -, um colossal universo de referências históricas da inteligência humana, para com eles apresentar uma argumentação geral sobre a formação histórica dos tempos institucionais do capitalismo contemporâneo. Ao analisar a estrutura das visões de mundo na formação histórica do capitalismo, o autor, no estudo da cultura, apresentava a

\footnotetext{
${ }^{25}$ Entre outros, os historiadores Lucien Febvre e Robert Mandrou resenharam o livro para a Revista dos Annales.
} 
reificação social como totalidade histórica e nessa caracterização críticodialética sua perspectiva anticapitalista se fazia presente como estrutura significativa na definição política do conjunto da sua obra. E por esses motivos é que entendo, repetindo o que disse no primeiro parágrafo deste artigo, Lucien Goldmann como um importante pensador marxista dissidente do século XX.

No primeiro dos seus ensaios metodológicos, publicado em 1948, Goldmann (1979: 55) assim afirma:

As obras de um pensador nada mais são que a expressão de uma concepção unitária e total do mundo e só é possível compreendê-las realmente a partir do instante em que se conseguir captar a estrutura do conjunto e compreender cada obra como parte de um todo, dentro do qual tem uma função e uma importância precisas que é necessário estabelecer. (Grifo no original).

No excerto apresentado, o autor supõe dois critérios de análise: a crítica imanente e a perspectiva relacional da totalidade. O historiador, diante do estudo sistemático do pensamento de um autor, tem de obrigatoriamente estabelecer como critério de análise a descoberta dos temas fundamentais da obra, sua coerência interna no conjunto dessa obra, estabelecer o que é um texto prioritário, essencial, em face de outros de menor alcance e importância, textos acidentais. E, ao proceder assim, nessa análise imanente terá como resultado um primeiro movimento de significados sobre a totalidade da obra. Para Goldmann, o historiador que tiver elaborada essa organização conceitual imanente da obra terá condições de "iniciar para valer" a sua pesquisa. Conhecer a integralidade da obra de um autor e dar-lhe coerência nos seus significados internos é afirmar uma compreensão imanente que exigirá de imediato serem essas estruturas significativas explicadas junto a outras estruturas ampliadas (quadros ideológicos do grupo social a que se vincula ou não o produtor da obra ou conexões com outros pensadores, outros autores contemporâneos ou não da obra que esteja estudando). A compreensão desse quadro ideológico ampliado dará sentido explicativo, coerência de significado aos resultados iniciais obtidos da análise sistemática do pensamento e obra do autor em estudo. A compreensão imanente da obra precisa ser explicada e justificada como sentido 
social diante da compreensão de estruturas ampliadas, momento, como já afirmei, em que o autor-obra tem de se encontrar como sujeito transindividual num dado grupo ou classe social. A compreensão das estruturas significativas da ação institucional do grupo ou classe social levará o historiador a explicar de modo cada vez mais amplo os significados da obra do autor que esteja estudando e com isso tem-se uma constatação: o verdadeiro autor da obra nunca é o indivíduo que a elaborou, mas o sujeito transindividual (que é o indivíduo em relação mediada como parte de um grupo ou classe social - a totalidade histórica). Desse modo, para Goldmann, a exegese biográfica de um autor é um elemento bastante secundário ${ }^{26}$ nos estudos de História Intelectual, pois pode auxiliar na montagem factual da historicidade. Mas o autor por si mesmo, como indivíduo, raramente consegue ter uma visão coerente de sua própria realidade, o que implica dizer que não é o que o autor diz sobre a sua obra que é de fato o termo a considerar, mas a visão de mundo coerente obtida da análise imanente da sua obra. Insisto, não é negar que uma obra não pertença a um autor, mas afirmar que é na coerência interna da obra (literária, filosófica ou historiográfica) que se pode perceber o alcance do conteúdo nela apresentado. Escreve Goldmann (1979: 84): “O artista não copia a realidade nem ensina verdades. Ele cria seres e coisas que constituem um universo mais ou menos vasto e unificado". Ora, se formalmente o historiador também faz isso, então esse "universo deve ter uma certa coerência e uma certa lógica interna" para se

\footnotetext{
${ }^{26} \mathrm{O}$ mesmo poderia ser dito para a questão das "influências" de um autor a outro. Para o autor, esse é um falso problema (GOLDMANN, 1979: 77). As influências intelectuais de um autor ou uma corrente de ideias sobre outro autor por si só não explicam nada da realidade material e ideológica da obra que está em elaboração. A pergunta-chave que deve sempre ser feita é porque o autor que se estuda sofreu essa influência e não outras em determinada circunstância de sua vida ou de produção da sua obra. No caso de Goldmann, que é o personagem deste artigo, pouco acrescenta saber que seu marxismo teve influências de Lukács. O importante a indagar é por que Lukács e não outra matriz, por que o Lukács de 1923 e não o Lukács "stalinista" das décadas de 1930-1950. Ao se responder a essas indagações a questão das influências desaparece e se percebe que são escolhas políticas atuando como estruturas significativas no fundamento ideológico da obra, na operacionalização ou não do máximo de consciência possível da obra desse autor (no caso a de Goldmann) como proposta política junto ao grupo/classe com o qual estivesse envolvido, intencionalmente ou não. Basta ver os significados políticos do isolamento de Goldmann na Universidade em que atuava e mesmo no quadro social da intelligentsia francesa e europeia com quem se relacionava e debatia para perceber que a posição outsider de Lukács em 1923 era a de retomar politicamente a aposta utópica da revolução autogestionária que historicamente se afirmara como possibilidade revolucionária nos primeiros anos da década de 1920.
} 
manter (GOLDMANN, 1979: 84). Assim, quanto mais rigorosamente coerente for apresentado o conteúdo, maior alcance poderá ter a obra como visão de mundo do autor na sua relação com o grupo/classe que o define com sujeito transindividual. Dependendo da qualidade da forma de apresentação, mais preciso e coerente é o máximo de consciência possível desse trabalho intelectual na organização política do grupo social do qual está emanado o autor.

$\mathrm{Na}$ sua concepção de História, Lucien Goldmann afirma "que o fundamento ontológico da História é a relação do homem com os outros homens, o fato de que o 'eu' individual só existe como pano de fundo da comunidade" e que "o que procuramos no conhecimento do passado é a mesma coisa que procuramos no conhecimento dos homens contemporâneos". E mais, se o estudo da História "nos apresenta uma importância prática" é porque com ele "aprendemos a conhecer os homens que em condições diferentes e com meios diferentes, inaplicáveis à nossa época, lutaram por valores e ideais, análogos, idênticos ou opostos aos que possuímos hoje", fato esse, diz Goldmann (1980: 22), que "nos dá consciência de fazer parte de um todo que nos transcende, a que no presente damos continuidade, e que os homens vindos depois de nós continuarão no porvir". Por isso em qualquer definição de História sempre terão de estar presentes na análise os "fatos passados, presentes e futuros" (GOLDMANN, 1980: 18). A História é sempre uma aposta no possível. Estudar a História é "tentar compreender as ações dos homens, os fins que perseguiram, a significação que para eles tinham seus comportamentos e suas ações" (GOLDMANN, 1980: 25, grifo no original).

Para concluir, o critério goldmanniano de "classe social", o elemento teórico mais importante apresentado no livro Ciências Humanas e Filosofia:

[...] as classes são os únicos grupos cujas escalas de valores são específicas, porque delas cada uma visa um ideal diferente de organização social de conjunto, de sorte que até as colaborações entre classes não podem ser mais do que um meio provisório e temporário para atingir fins essencialmente diferentes. (GOLDMANN, 1980: 87). 
Acima, a precisão da definição: escalas de valores ou a materialidade definida no ato ideológico. "Escala de valores" significa posição ideológica do grupo/classe na relação contraditória com os demais grupos/classes. Só é possível definir a historicidade de uma classe social percebendo-a em perspectiva dialética emanentista, isto é, em ato relacional fundamental com as demais classes - a sua função no interior do processo produtivo capitalista. No capitalismo a função na produção coloca todas as classes sociais em relação. É sempre da produção material das mercadorias que se constrói o edifício social capitalista. O processo produtivo organiza as classes sociais e a práxis das classes sociais reorganiza permanentemente o processo produtivo. Dessa relação emanam as visões de mundo das classes. Se uma visão de mundo é a consciência possível de uma classe, a visão de mundo é, portanto, o fato primordial que o historiador deve compreender e explicar à luz do processo produtivo, o que significa dizer que o trabalho de História das Ideias ou de História dos Intelectuais, na perspectiva goldmanniana, é sempre um trabalho de investigação sobre as contradições fundamentais do processo produtivo capitalista, já que o trabalho intelectual, tanto o do investigador como aquele que é o objeto de estudo, está sempre mediado e emanado das contradições históricas da organização do processo produtivo.

\section{Referências}

ADLER, M. Conselhos operários e revolução. Coimbra: Centelha, 1976.

ANDERSON, P. Considerações sobre o marxismo ocidental. São Paulo: Editora Brasiliense, 1989.

ARATO, A. A antinomia do marxismo clássico: marxismo e filosofia. In: HOBSBAWM, E. (Org.). História do marxismo IV. Rio de Janeiro: Paz e Terra, 1986.

ARATO, A.; BREINES, P. El joven Lukács y los origenes del marxismo occidental. México: Fondo de Cultura Económica, 1986.

BERNARDO, J. Labirintos do fascismo: na encruzilhada da ordem e da revolta. Porto: Afrontamento, 2003. 
COHEN, M. The wager of Lucien Goldmann: tragedy, dialectics, and Hidden God. Princeton, New Jersey: Princeton University Press, 1994.

FREDERICO, C. Sociologia da cultura: Lucien Goldmann e os debates do século XX. São Paulo: Cortez, 2006.

GOLDMANN, L. Sciences humaines et philosophie. Paris: Presses Universitaires de France, 1952.

GOLDMANN, L. Introduction à la philosophie de Kant. Paris: Éditions Gallimard, 1967a.

GOLDMANN, L. Origem da dialética: a comunidade humana e o universo em Kant. Rio de Janeiro: Paz e Terra, 1967b.

GOLDMANN, A. "L'Auteur". In: GOLDMANN, L. Situation de la critique racinienne. Essai. Paris: L'Arche, 1971a. p. 122-124.

GOLDMANN, L. Situation de la critique racinienne (Essai). Paris: L'Arche, $1971 b$.

GOLDMANN, L. Dialética e cultura. Rio de Janeiro: Paz e Terra, 1979.

GOLDMANN, L. Ciências humanas e filosofia. São Paulo: Difel, 1980.

GOLDMANN, L. Epistemologia e filosofia política. Lisboa: Editorial Presença, 1984.

GOLDMANN, L. Le Dieu caché: étude sur la vision tragique dans les pensées de Pascal et dans le théâtre de Racine. Paris: Gallimard, 1988.

JAY, M. A imaginação dialética: história da Escola de Frankfurt e do Instituto de Pesquisas Sociais (1923-1950). Rio de Janeiro: Contraponto, 2008.

JUDT, T. O peso da responsabilidade: Blum, Camus, Aron e o século XX francês. Rio de Janeiro: Objetiva, 2014.

KOLAKOWSKY, L. Las principales corrientes del marxismo. v. 3: La crisis. Madri: Alianza Editorial, 1983.

LOTTMAN, H. R. A Rive Gauche: escritores, artistas e políticos em Paris 1930-1950. Rio de Janeiro: Guanabara, 1987.

LÖWY, M. Romantismo e messianismo: ensaios sobre Lukács e Walter Benjamin. São Paulo: Perspectiva, 1990. 
LÖWY, M.; NAIR, S. Lucien Goldmann: ou a dialética da totalidade. São Paulo: Boitempo Editorial, 2008.

LUKÁCS, G. História e consciência de classe: estudos sobre a dialética marxista. São Paulo: Martins Fontes, 2003.

MANN, M. Fascistas. Rio de Janeiro: Record, 2008.

MAZOWER, M. Continente sombrio: a Europa no século XX. São Paulo: Companhia das Letras, 2001.

MERLEAU-PONTY, M. As aventuras da dialética. São Paulo: Martins Fontes, 2006.

PAXTON, R. O. A anatomia do fascismo. São Paulo: Paz e Terra, 2007.

PIAGET, J. Sabedoria e ilusões da filosofia. São Paulo: Abril Cultural, 1978 (Os Pensadores).

RIDING, A. Paris, a festa continuou: a vida cultural durante a ocupação nazista, 1940-1944. São Paulo: Companhia das Letras, 2014.

TERTUliAN, N. Georg Lukács: etapas de seu pensamento estético. São Paulo: Ed. Unesp, 2008.

Recebido em: 31 de julho de 2019 Aceito em: 05 de dezembro de 2019 